\title{
Validation of an HPLC Method Devised for the Quan- titative Determination of Ropivacaine in Drug-Delivery Systems
}

\author{
Ana Laís Nascimento VIEIRA ${ }^{1}$, Michelle FRANZ-MONTAN ${ }^{2}$, Luis Fernando CABEÇA ${ }^{3}$, Eneida DE \\ PAULA $^{1^{*}}$
}

${ }^{1}$ Department of Biochemistry and Tissue Biology, Institute of Biology, University of Campinas (Unicamp), Campinas, SP, Brazil
2 Department of Physiological Sciences, Piracicaba Dental School, Unicamp, Piracicaba, SP, Brazil
${ }^{3}$ Department of Chemistry, Federal Technological University of Paraná, Londrina, PR, Brazil

*Corresponding author: Dr. Eneida de Paula (Ph.D, full professor), Department of Biochemistry and Tissue Biology, Institute of Biology, University of Campinas - Unicamp, Rua Monteiro Lobato, 255, CEP: 13083-862, Campinas, São Paulo, Brazil, Tel: +55 -19- 35216143/Fax: +55-19-35216185; E-mail: depaula@unicamp.br

\begin{abstract}
Ropivacaine (RVC) is a long acting local anesthetic, synthesized in the S enantiomeric form. This work describes the development of an analytical method and validation parameters that assured acceptable characteristics (suitability, reliability and feasibility) to quantify RVC in the presence of drug-delivery carriers such as cyclodextrins and liposomes. High performance liquid chromatography (HPLC) was performed using a reversed-phase C18 column, a mixture of acetonitrile and phosphate buffer $\mathrm{pH} 8.0(60: 40, \mathrm{v}: \mathrm{v})$ as the mobile phase, $1.2 \mathrm{~mL} / \mathrm{min}$ flow rate and oven temperature of $30{ }^{\circ} \mathrm{C}$; Ropivacaine was detected by UV absorption, at $240 \mathrm{~nm}$. The results showed that the analytical method is accurate, reproducible, robust and linear over the concentration range of $0.08-1.16 \mathrm{mM}$ RVC. The method was applied to detect the in vitro release profile of the anesthetic loaded in two different drug-delivery systems: i) RVC encapsulated into egg phosphatidylcholine liposomes, and ii) RVC complexed with hydroxypropyl-beta-cyclodextrin (HP- $\beta C D)$. The release kinetics rate was significantly slower for the RVC-HP- $\beta C D$ complex than for liposomal RVC or the free drug (RVC in solution). To explain that, diffusion ordered spectroscopy (1H-NMR DOSY) experiments were conducted. The results confirmed the stronger interaction of the anesthetic with HP- $\beta C D$ (association constant, Ka $=128 \mathrm{M}^{-1}$ ) than with liposomes $\left(\mathrm{Ka}=22 \mathrm{M}^{-1}\right)$, in accordance with the release kinetic data. In conclusion, the HPLC method described was proven suitable for the quantification of ropivacaine in drug-delivery systems.
\end{abstract}

Keywords: Analytical methods; Validation; HPLC; Ropivacaine; Liposomes; Cyclodextrins

\section{Introduction}

Local anesthetics are used to alleviate or eliminate acute and chronic pain ${ }^{[1-3]}$. Ropivacaine (RVC) is a long acting local anesthetic with a chemical structure closely related to other amino-amides cyclic agents: mepivacaine and bupivacaine ${ }^{[3,4]}$. It is synthesized in the $\mathrm{S}$ enantiomeric form, which is less toxic to the Central Nervous and Cardiac systems ${ }^{[5]}$. Furthermore, studies in animals and humans suggest that RVC induces less motor block compared to bupivacaine, given the greater selectivity of the $\mathrm{S}$ isomer to sensory nerve fibers ${ }^{[6]}$. The use of drug-delivery systems (DDS) such as liposomal formulations and cyclodextrin-inclusion complexes, have been proposed to improve the solubility and bioavailability of poorly soluble local anesthetics ${ }^{[7,8]}$. Nowadays, several DDS based on these two carriers can be found among the commercially available local anesthetics products ${ }^{[9,10]}$.

HPLC is the method-of-choice for quantification of drugs in different fluids due to its sensitivity, reproducibility and specificity. Reports on the literature describe precise methods for the quantification, using HPLC, of local anesthetics in serum ${ }^{[11-13]}$,
Received date: August 25, 2018 Accepted date: October 18, 2018 Published date: October 25, 2018

Citation: Vieira, A.L.N., et al. Validation of an HPLC Method Devised for the Quantitative Determination of Ropivacaine in Drug-Delivery Systems. (2018) J Anal Bioanal Sep Tech 3(1): 14- 20.

Copyright: (C) 2018 Vieira, A.L.N. This is an Open access article distributed under the terms of Creative Commons Attribution 4.0 International License. 
urine $^{[14]}$ and PLGA microspheres ${ }^{[15]}$. When a new method is developed it is important to validate it, to confirm it is suitable for the intended purposes. This work depicts the validation parameters specified- either by the International Conference on Harmonization of Technical Requirements for Registration of Pharmaceuticals for Human Use guidelines, $\mathrm{ICH}^{[16]}$ or by the Brazilian National Health Surveillance Agency ${ }^{[17]}$ - to validate an analytical method with acceptable characteristics of suitability, reliability and feasibility to quantify ropivacaine. Moreover, the validated method was applied to determine the in vitro release profile of RVC from two (liposomal and HP- $\beta C D$-based) DDS formulations. The improved sustained release evoked by HP- $\beta C D$ was explained by $1 \mathrm{H}-\mathrm{NMR}$ (DOSY) experiments that detected the higher affinity of the local anesthetic for HP- $\beta$-cyclodextrin than for egg-phosphatidyl choline liposomes.

\section{Experimental materials}

Ropivacaine hydrochloride (purity $=98.5 \%$ ) was donated by Cristália Prod Quím Farm Ltd (Itapira, SP, Brazil). Ropivacaine hydrochloride (reference standard) was obtained from USP (American Pharmacopeia; purity $=94.66 \%$ ). Hydroxypropyl- $\beta$-cyclodextrin, HP- $\beta C D$ (Kleptose $\mathrm{HP}^{\circledR}$ ) was obtained from Roquette Serv Tech Lab (Lestrem, Cedex, France). HEPES buffer and egg phosphatidylcholine (egg PC, purity > 99\%) were purchased from Sigma Chem Co. (St. Louis, MO, USA). All other reagents were of analytical grade. Ultrapure water (Elga Maxima System, Elga, High Wycombe, UK) was used throughout the experiments. HPLC-grade acetonitrile was purchased from Merck ${ }^{\circledR}$.

\section{Preparation of Drug delivery systems for RVC}

Inclusion complexation of RVC with HP-BCD: A solid inclusion complex was obtained by mixing appropriate amounts of HP- $\beta C D$ and RVC to 1:1 molar ratio ${ }^{[19]}$. The samples were shaken for $24 \mathrm{~h}$ at room temperature prior to freeze-drying, at -20 ${ }^{\circ} \mathrm{C}^{[7]}$. The lyophilized powder was suspended in $20 \mathrm{mM}$ HEPES (with $150 \mathrm{mMNaCl}, \mathrm{pH} 7.0$ ) buffer to a final $8 \mathrm{mM}(0.25 \%)$ RVC concentration.

Liposomal RVC formulation: Large Multilamellar Vesicles (LMV) were prepared from aliquots of egg PC and $\alpha$-tocopherol (1:0.01mol\%), taken from stock chloroform solutions. The samples were evaporated under flowing $\mathrm{N}_{2}$ and kept under vacuum $(2 \mathrm{~h})$ at room temperature to remove any residual solvent. The obtained lipid film was either suspended in $20 \mathrm{mM}$ HEPES buffer with $150 \mathrm{mM} \mathrm{NaCl}, \mathrm{pH} 7.0$ (control), or in $0.25 \% \mathrm{RVC}$ solution, prepared in the same buffer. The samples were then vortexed for $5 \mathrm{~min}$, to form the LMV.

Large unilamellar vesicles (LUV) were obtained by extrusion of the $\mathrm{LMV}^{[4]}$ through two polycarbonate membranes $\left(\right.$ Poretics $\left.{ }^{\circledR}\right)$, with controlled pore sizes $(0.4 \mathrm{~mm})$, for 12 times under $\mathrm{N}_{2}$ pressure (40 psi or $3.0 \mathrm{kgf} / \mathrm{cm}^{2}$ ), at room temperature.

\section{Validation study for the quantification of Ropivacaine by HPLC}

The chromatographic apparatus consisted of a HPLC Merck Hitachi, with a L2130 pump coupled with an L2200 auto-sampler and a L2455 diode array detector. For data collection and calculation, the EzChrom Software (3.3.2 SP2) was used. The experiments were conducted at Medley S/A Ind. Farm., Campinas-SP, Brazil.

The chromatographic condition was optimized using a C18 column (Purospher Star RP 18 endcapped- 150 x $4.6 \mathrm{~mm}$ - particle size $5 \mu \mathrm{m}$, Merck). The mobile phase consisted of a mixture of acetonitrile and phosphate buffer (1 $\mathrm{M} \mathrm{NaHPO}_{4}{ }^{2-}$ and $0.5 \mathrm{M} \mathrm{NaH}_{2} \mathrm{PO}_{4}^{-}, \mathrm{pH} 8.0$ ), 60: 40 v:v. The mobile phase was filtered through a $0.45 \mu \mathrm{m}$ Millipore ${ }^{\circledR}$ membranes; flow rate was set to $1.2 \mathrm{~mL} / \mathrm{min}$, and oven temperature to $30{ }^{\circ} \mathrm{C}$. The monitoring wavelength was $240 \mathrm{~nm}$ and the injection volume was $10 \mu \mathrm{L}$, according to Jönsson and coworkers ${ }^{[15]}$ and USP $41^{[18]}$.

Stock and working solutions: A stock standard solution of RVC in the mobile phase was prepared at $1.66 \mathrm{mM}$. Working standard solutions ( $\mathrm{RVC}=0.08$ to $1.16 \mathrm{mM}$ ) were prepared by diluting a stock solution in 20 mMHEPES buffer with $0.9 \% \mathrm{NaCl}, \mathrm{pH} 7.0$.

The validation of the analytical methodology was conducted under the guidelines established by international[16] and nationa ${ }^{[17]}$ regulatory agencies. The Validation Manager software (version 2.20 E, Merck $^{\circledR}$ ) was used to calculate the parameters: selectivity, linearity, precision, accuracy, robustness, quantification and detection limits, and stability.

Selectivity / Specificity and Peak Purity: A method is considered specific when it is able to provide response for a single analyte. The samples analyzed in this assay were: standard RVC solution; placebo suspension (containing all the formulation components but RVC), RVC complexed with HP- $\beta C D(R V C: H P-$ $\beta C D)$ and RVC encapsulated in liposomes $\left(\mathrm{LUV}_{\mathrm{RVC}}\right)$.

The samples were prepared at $0.76 \mathrm{mMRVC}$, diluted in 20 mMHEPES buffer with $0.9 \% \mathrm{NaCl}, \mathrm{pH} \mathrm{7,0}$ and injected in triplicates. The chromatograms for the placebo, standard RVC solution and DDS were evaluated in order to check for interfering co-eluting in the wavelength $(240 \mathrm{~nm})$ chosen for RVC quantification. Recovery was calculated in comparison to the standard RVC solution, to confirm the specificity of the method.

Linearity: Linearity was measured within the concentration range of $0.08-1.16 \mathrm{mM}$ RVC. Samples at each concentration were injected in triplicate, in three consecutive days.

The least square method was used to determine the calibration curve. The analyzed species were USP-standards, containing only the examined compound. The calibration curve was prepared with eight different concentrations and three repetitions per concentration level. Analysis of variance of the regression leads to the determination of the slope and validity of the regression line; only correlation coefficients (r) higher than 0.99 were accepted $^{[16,17]}$.

Accuracy: Accuracy refers to the proximity between the analyzed concentration value of a sample, and the known concentration value, calculated by the calibration curve (linearity). A method is considered accurate if the theoretical recovery of $100 \%$ got included within the confidence interval.

Samples of the two DDS (RVC: HP- $\beta C D$ and $L_{U V} V_{R V C}$ ) containing $8 \mathrm{mM}$ ropivacaine each, were diluted in HEPES buffer $\mathrm{pH} 7.0$ to three levels of concentration $(0.66 \mathrm{mM}=80 \%, 0.83$ $\mathrm{mM}=100 \%$ and $0.99 \mathrm{mM}=120 \%$ ). The samples were injected in triplicate, in three consecutive days, and the recovery was cal- 
Citation: Vieira, A.L.N., et al. Validation of an HPLC Method Devised for the Quantitative Determination of Ropivacaine in Drug-Delivery Systems. (2018) J Anal Bioanal Sep Tech 3(1): 14- 20.

culated according to the calibration curve. The accuracy of the method was evaluated over the linearity range.

Linearity range: For the samples describe above measurements were repeated 3 times, and the calculated concentrations were determined with the calibration curve. A fitting curve for the calculated concentrations and the true concentrations was calculated and the mean recovery associated with a confidence interval was calculated.

Precision: Precision evaluates the proximity of the obtained results, in a multiple series of measurements of the same sample. The repeatability parameter describes the correlation between the results within a short period of time, obtained by the same analyst, in the same instrument. As for intermediate precision, it shows the correlation between the results obtained from the same analyst/instrumentation, but obtained on different days.

The precision of an analytical method can be expressed as the standard deviation and relative standard deviation (coefficient of variation) of a series of measures. Here, it was determined from 6 samples containing $0.83 \mathrm{~m}$ MRVC (corresponding to $100 \%$ theoretical recovery) prepared by dilution of the drug-delivery system in HEPES buffer, as described above; samples were injected in triplicate. The same procedure was repeated on the following day, for determination of the intermediate precision.

The precision was expressed as the relative standard deviation (RSD), calculated according to equation 1 :

$R S D=S D \div A C D \times 100 \quad$ Eq. 1

Wherein SD is the standard deviation and ACD, the average concentration determined.

The maximum acceptable RSD value must be set accordingly to the methodology, analyte concentration in the sample, type of matrix and purpose of the method, but values greater than $5 \%$ for intermediate precision (determined on different days) and $2 \%$ for repeatability are not acceptable ${ }^{[16,17]}$.

Robustness: The robustness of an analytical method is a measure of its ability to resist to small and deliberate variations of the analytical parameters, indicating their confidence during normal use. Samples were prepared in triplicate, following the same procedure described for precision.

The following changes were conducted to evaluate the robustness of the method: a) Flow rate: 1.0 and $1.4 \mathrm{~mL} / \mathrm{min}$; b) oven temperature $=25^{\circ} \mathrm{C}$; c) mobile phase 70:30 and 50:50 (v: v), acetonitrile/buffer.

The samples were injected in triplicate and the recovery of each modified condition was calculated, relatively to the original one. The mean recovery of each set of (n) values was calculated using equation 2 :

$\frac{\sum_{i=1}^{n} m i}{n}=$ recovery $(\%)$

Eq. 2

Where $m_{i}$ describes the percentage of recovery in each sample belonging to a given (modified) condition and $n$ is the number of data in that condition.

\section{Stability of solutions containing RVC (standard and sam- ples)}

The stability test intends to determine the time during which the drug in both, standard solution and sample retains within specified limits, the same properties and characteristics of the time of its preparation. Samples were prepared in triplicate following the same procedure described in accuracy. Two standard solutions were prepared with $0.76 \mathrm{mM} \mathrm{RVC}$, diluted in HEPES buffer. The solutions were injected in triplicate at $0,6,12,24$, 42 and $48 \mathrm{~h}$ after preparation. The recovery of the samples was calculated according to the initial response (time $0 \mathrm{~h}$ ).

\section{In vitro release kinetics of the RVC drug-delivery system}

The in vitro release test was performed in order to evaluate the previously validated methodology, and also to determine the release profile of RVC from the liposomal and cyclodextrin-based $\operatorname{DDS}^{[20]}$. The in vitro release test was carried out in Franz-type vertical diffusion cells (Disa, Magenta Milano, Italy), with $0.64 \mathrm{~cm}^{2}$ of permeation area and a $4 \mathrm{~mL}$ receiver compartment. The following formulations were tested: $\mathrm{RVC}$ in solution (free RVC), $\mathrm{LUV}_{\mathrm{RVC}}$ and RVC: HP- $\beta \mathrm{CD} ; 400 \mu \mathrm{L}$ of each formulation was placed at the donor compartment. The receptor chamber was filled with degassed buffer (20 m MHEPES with $150 \mathrm{mM}$ $\mathrm{NaCl}, \mathrm{pH} 7.0)$, kept under magnetic stirring (300 rpm) at $37^{\circ} \mathrm{C}$. A cellulose membrane (Spectrapore ${ }^{\circledR}$, with molecular exclusion pore of $1000 \mathrm{Da}$ ) was used to separate the two compartments.

Samples were periodically withdrawn (15 and $30 \mathrm{~min}$, $1,2,3,4,6$ and $8 \mathrm{~h}$ ) from the receptor compartment (with subsequent replacement with fresh buffer, in equal volume) and analyzed by HPLC, as previously described.

\section{NMR experiments}

NMR diffusion experiments with pulsed field gradient spin-echo were used to determine the association constants between ropivacaine and the carriers (liposomes or HP- $\beta C D$ ). Spectra were run in a Varian INOVA-500 spectrometer operating at 499.89 $\mathrm{MHz}$ for ${ }^{1} \mathrm{H}$, with the DgcteSL (gradient compensated stimulated echo spin lock) HR-DOSY sequence. For all experiments, an optimized diffusion time of $0.06 \mathrm{~s}$ was used, with 25 different pulsed gradient amplitudes, from $0.1067-0.5334 \mathrm{~T} / \mathrm{m}$. Equimolar $(8 \mathrm{mM})$ concentrations of RVC, HP- $\beta C D$ and liposomes were used. The bound molar fraction (f) and association constants $(\mathrm{Ka})$ of ropivacaine to each of the carrier (cyclodextrins and liposomes) systems were calculated from the diffusion coefficients (D), according to eq. $4,5^{[21]}$ and references therein:

$\mathrm{D}_{\text {obs }}=\mathrm{f}_{\text {bound }} \cdot \mathrm{D}_{\text {bound }}+\mathrm{f}_{\text {free }} \cdot \mathrm{D}_{\text {bound }} \quad$ Eq. 3

$f_{\text {bound }}=\frac{\left(D_{\text {free }}-D_{\text {observed }}\right)}{\left(D_{\text {free }}-D_{\text {carrier }}\right)}$ Eq. 4

$K a=\frac{f_{\text {bound }}}{\left(\left(1-f_{\text {bound }}\right)\left([\text { carrier }]-f_{\text {bound }}[R V C]\right)\right)} \quad$ Eq. 5

\section{Results and Discussion}


In order to enhance the action of RVC aiming at its clinical application, our group has successfully described the use of liposomes and cyclodextrin-based DDS ${ }^{[4,9,19,22-24]}$. In the development of DDS, analytical methods for the quantification of local anesthetics are required, that allow precise drug determination even in the presence of the carriers. The following results describe the validation of a HPLC methodology, for RVC analysis in DDS.

\section{Validation study}

Figure $1 \mathrm{~B}$ shows the chromatogram obtained with a standard ropivacaine solution, and Table 1 shows the parameters used to evaluate the suitability of the method.

Table 1: Parameters obtained in the chromatographic run of ropivacaine, to evaluate the suitability of the method.

\begin{tabular}{|c|c|}
\hline Theoretical plates & 11146 \\
\hline Capacity factor & 2.37 \\
\hline Asymmetry & 1.13 \\
\hline Peak purity & 1.0 \\
\hline
\end{tabular}

No other peaks or interferences were determined at the retention time corresponding to the RVC peak in the placebo, standard or DDS chromatograms (Figs. 1A, 1B and 1C, respectively) indicating the method is specific to RVC detection.

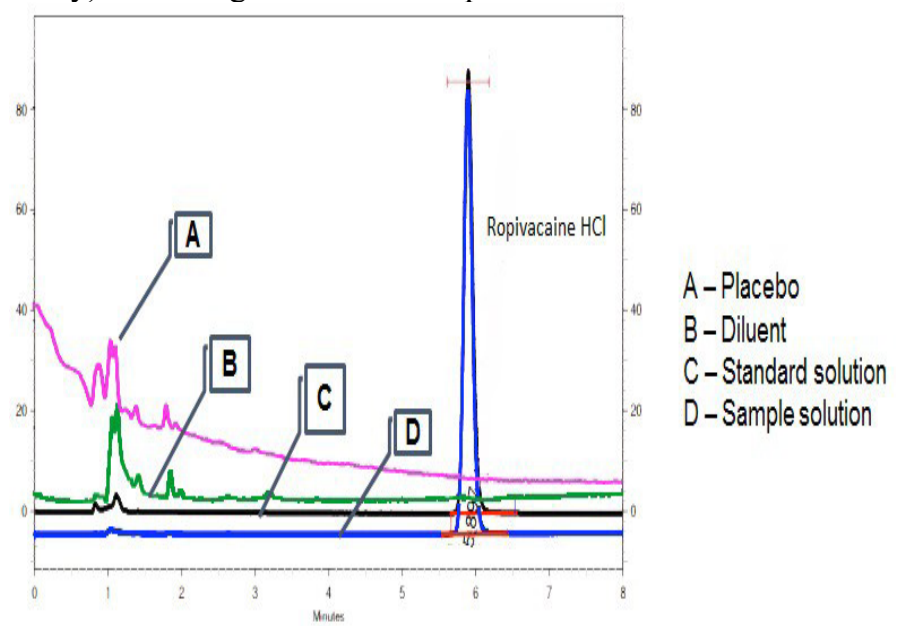

Figure 1: Chromatograms of placebo, diluent and RVC (standard and prepared) samples

The recovery of the sample solution was $101.8 \% \pm$ $0.3 \%$ confirming the selectivity and specificity of the method employed. The peak purity of standard (Fig. 2A) and ropivacaine-in-solution (Fig. 2B) samples was also evaluated. These experiments attested the purity of the RVC peak determined in the tested condition, validating the parameters: selectivity, specificity and peak purity of the analytical ${ }^{[16,17]}$.
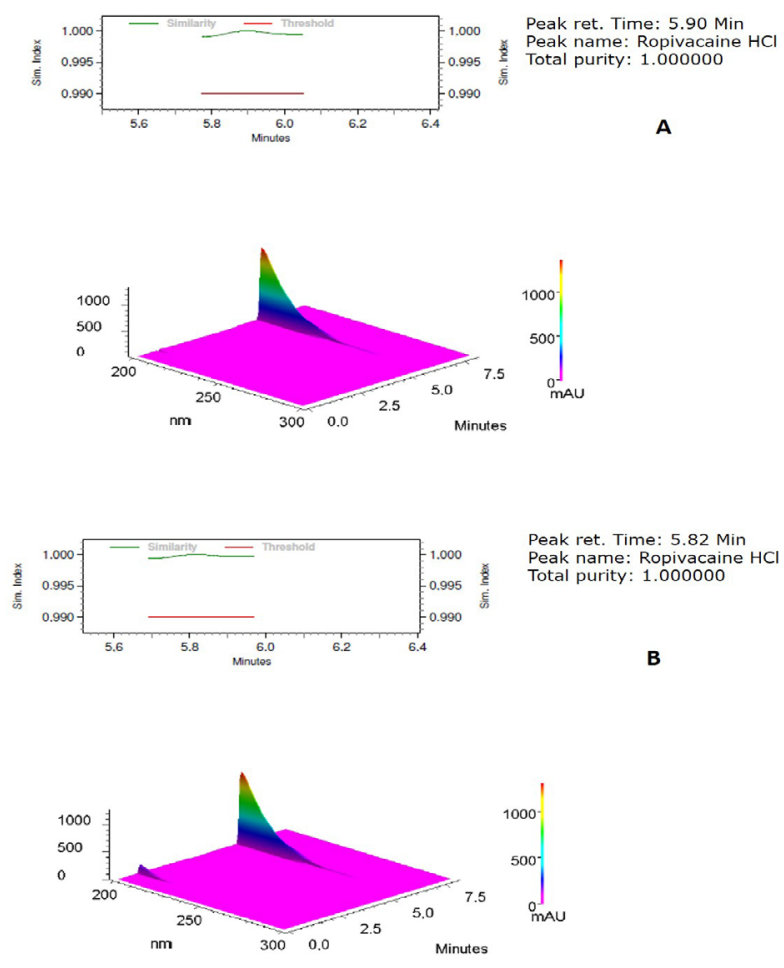

Figure 2: Chromatogram of standard (A) and prepared (B) RVC sample.

The linearity of the method was investigated using eight freshly prepared standard solutions of ropivacaine, in the concentration range of 0.08 to $1.16 \mathrm{mM}$. The calibration curve obtained by plotting the RVC peak area $v s$ the concentration of standard solution was linear in throughout the analyzed range, with a correlation coefficient of $0.99996(n=24)$ (Fig. 3).

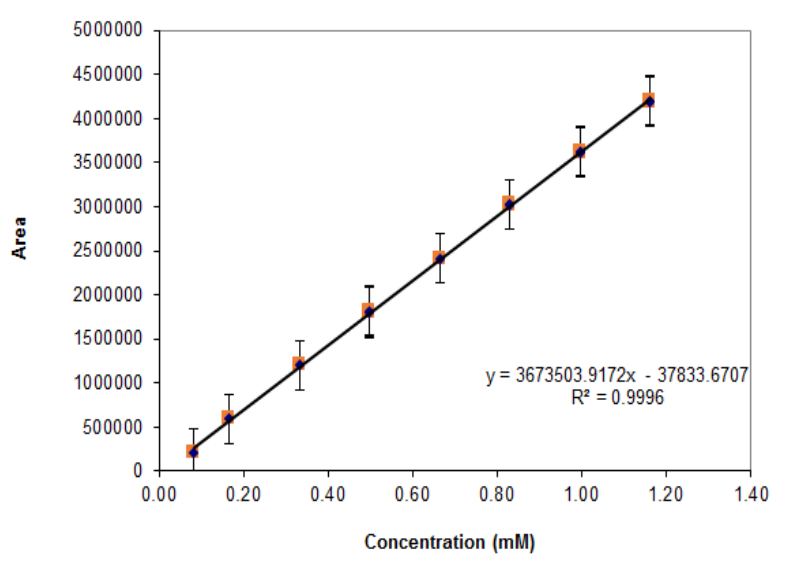

Figure 3: Linearity plot. Confidence level $=99.00$.

The accuracy was demonstrated by the recovery of known amounts of RVC, according Table 2.The mean recovery data remained between a strict interval (100-102\%) while the coefficient of variation was lower than $2.0 \%$ (Table 2), numbers acceptable and suitable for a HPLC method. 
Citation: Vieira, A.L.N., et al. Validation of an HPLC Method Devised for the Quantitative Determination of Ropivacaine in Drug-Delivery Systems. (2018) J Anal Bioanal Sep Tech 3(1): 14- 20.

Table 2: Mean recovery of ropivacaine, as quantified by the HPLC method.

\begin{tabular}{|l|c|c|c|c|}
\hline $\begin{array}{l}\text { Drug Delivery } \\
\text { System }\end{array}$ & \multicolumn{2}{|c|}{ Liposomal RVC } & \multicolumn{2}{c|}{ RVC:HP- $\beta$ CD complex } \\
\hline Level & $\begin{array}{c}\text { Mean } \\
\text { recovery } \\
(\%)\end{array}$ & $\begin{array}{c}\text { Mean } \\
\text { recovery } \\
(\%)\end{array}$ & $\begin{array}{c}\text { Coefficient } \\
\text { of variation } \\
(+/-)\end{array}$ & $\begin{array}{c}\text { Coefficient } \\
\text { of variation } \\
(+/-)\end{array}$ \\
\hline $80 \%(0.66 \mathrm{mM})$ & 101.47 & 101.73 & 0.42 & 0.18 \\
\hline $100 \%(0.83 \mathrm{mM})$ & 101.50 & 102.27 & 0.90 & 0.49 \\
\hline $120 \%(0.99 \mathrm{mM})$ & 101.40 & 101.36 & 0.58 & 0.03 \\
\hline
\end{tabular}

The intra-day precision was evaluated at $100 \%$ concentration level. The intermediate precision was evaluated in the same solutions, at different days. Values shown in Table 3 demonstrate the good precision of the method, according to required specifications ${ }^{[16,17]}$. The method was found robust in all variations tested: temperature (Fig.4A), flow (Fig.4B) and composition of mobile phase (Fig.4C), since the recovery of ropivacaine remained between 95.0 to $105.0 \%$.
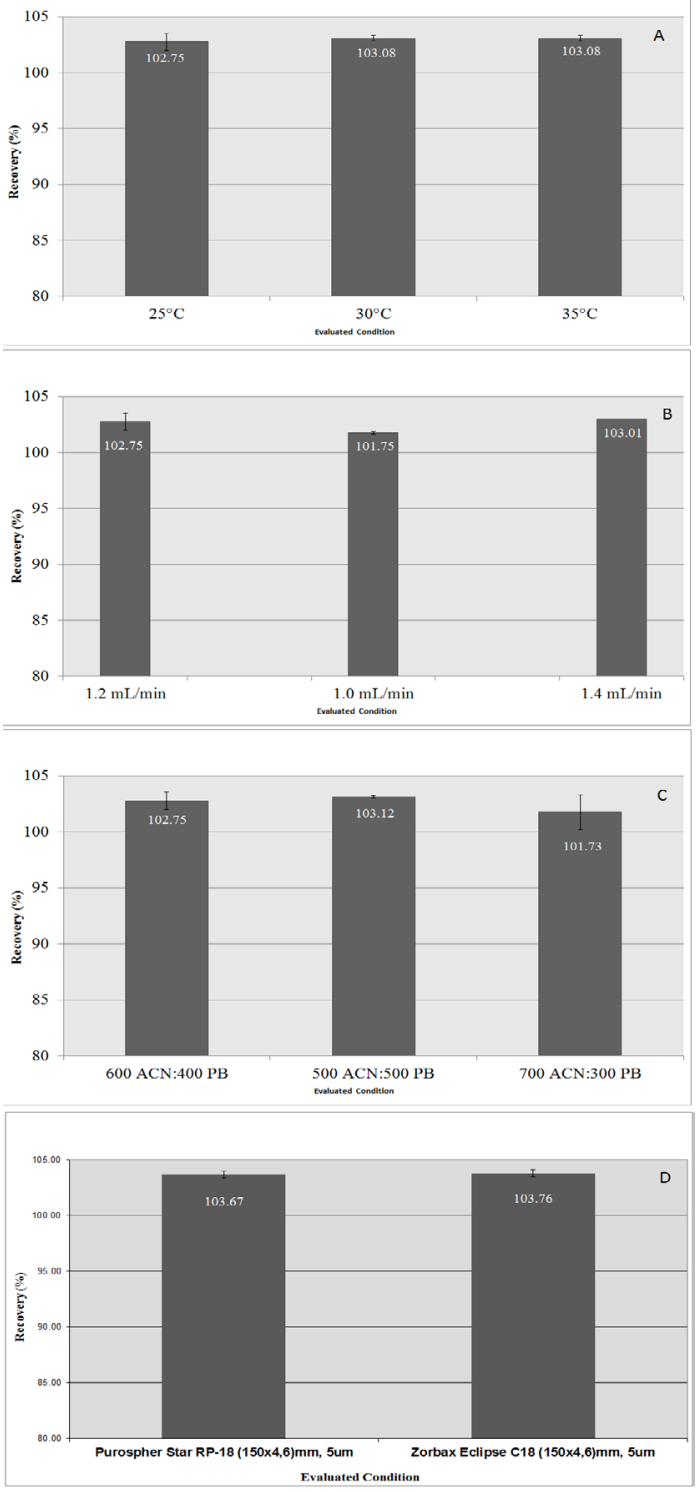

Figure 4: Robustness of the HPLC analytical method.
Table 3: Variance of repeatability, and intermediate precision.

\begin{tabular}{|l|c|c|c|c|}
\hline $\begin{array}{l}\text { Drug Delivery } \\
\text { System }\end{array}$ & \multicolumn{2}{|c|}{ Liposomal RVC } & \multicolumn{2}{c|}{ RVC:HP- $\beta C D$ complex } \\
\hline & $\begin{array}{c}\text { Mean } \\
\text { recovery } \\
(\%)\end{array}$ & $\begin{array}{c}\text { Mean } \\
\text { recovery } \\
(\%)\end{array}$ & $\begin{array}{c}\text { Variation } \\
\text { coefficient } \\
(+/-)\end{array}$ & $\begin{array}{c}\text { Variation } \\
\text { coefficient } \\
(+/-)\end{array}$ \\
\hline Repeatability & 102.79 & 102.46 & 0.39 & 0.39 \\
\hline $\begin{array}{l}\text { Intermediate } \\
\text { Precision }\end{array}$ & 103.70 & 102.50 & 0.47 & 0.48 \\
\hline
\end{tabular}

In the stability study, standard solutions of RVC were stable for at least $48 \mathrm{~h}$ after its preparation, while samples containing RVC ( $\mathrm{LUV}_{\mathrm{RVC}}$ or RVC: HP- $\beta \mathrm{CD}$ ) were stable for up to $24 \mathrm{~h}$. After this time, the drug content decreased, which may be due to sample deposition inside the vial, influencing the stability time of the working samples.

Overall, the data presented here validates the analytical method for quantification of ropivacaine by HPLC, according to the parameters as required by ICH and ANVISA ${ }^{[16,17]}$.

\section{In vitro release test}

The validated methodology for RVC quantification was applied in the in vitro release tests, performed to determine the release profile of RVC from two different (liposome and cyclodextrin-based) DDS. The anesthetic release from $\mathrm{LUV}_{\mathrm{RVC}}$ and RVC: HP- $\beta C D$ samples were compared to that of free RVC (Fig.5).

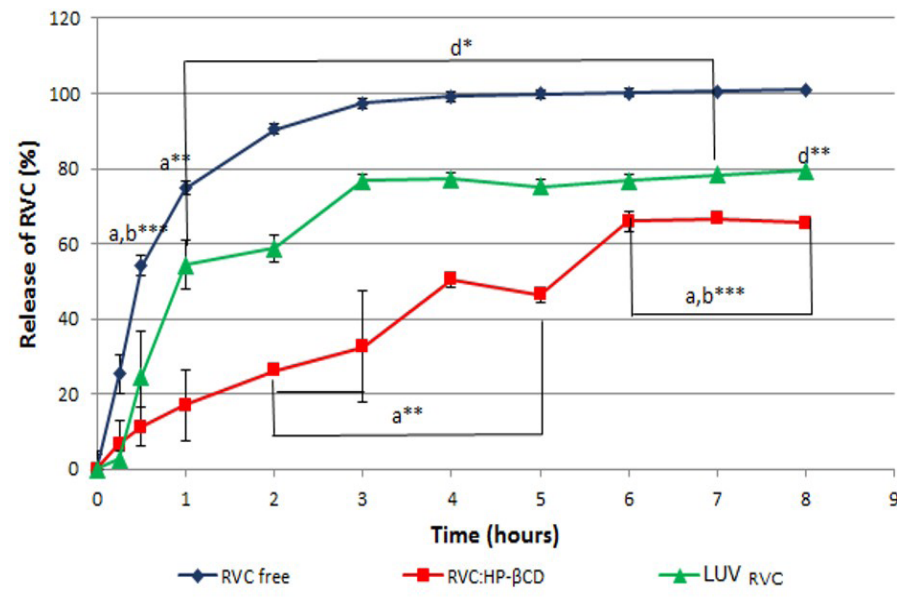

Figure 5: Release kinetics of RVC (free, complexed and encapsulated).

For the free RVC sample, $50 \%$ of the anesthetic was released into the receptor solution after $30 \mathrm{~min}$. Encapsulation in liposomes diminished the release rate of RVC; the curve showed a slow onset and almost twice the time $(50 \mathrm{~min})$ was required for 50\% release (Fig.5). Moreover, the RVC: HP- $\beta$ CD complex showed the slow estrelease rate, in comparison to free or liposome-encapsulated RVC ( $3 \mathrm{~h}$ for $50 \%$ release in the receptor chamber) (Fig. 5). These results are indicative of a greater affinity of the anesthetic for HP- $\beta C D$ than for the liposomes. Also, they agree with previous reports in the literature, for RVC encapsulated in egg PC: cholesterol: $\alpha$-tocopherol (4:3:0.07 mol\%) liposomes ${ }^{[4]}$ or RVC- $\beta C D^{[19]}$, for which the time for $50 \%$ release of the anesthetic was $75 \mathrm{~min}$ and $60 \mathrm{~min}$, respectively. Regarding the pharmacological properties of LA, which site of action is the axon membrane; both DDS would provide an increase in 
drug concentration at the site of action.

\section{NMR tests}

Finally, NMR diffusion ordered spectroscopy (DOSY) has been used to determine the association constants $(\mathrm{Ka})$ between RVC and liposomes or HP- $\beta C D$, as described before ${ }^{[21]}$. The experiment allowed the determination of the diffusion constants of the samples, taken in a gradient of magnetic fields, allowing the estimation of the fraction of RVC bound to each carrier (liposomes and HP- $\beta C D$ ), as well as the association constants (Table 4).

Table 4: Diffusion coefficients (D) for RVC, HP- $\beta C D$, liposomes, RVC:HP- $\beta C D$ and $L U V_{R V C}$, and association constants (Ka) of RVC in the binary systems: RVC:HP- $\beta C D$ and $\mathrm{LUV}_{\mathrm{RVC}}$, as measured in DOSY-NMR experiments. $600 \mathrm{MHZ}, \mathrm{D}_{2} \mathrm{O}, 25^{\circ} \mathrm{C}, \mathrm{pH} 7$; residual HDO signal $(4.68 \mathrm{ppm})$ was used as reference.

\begin{tabular}{|l|l|l|l|l|}
\hline $\begin{array}{l}\text { Drug Delivery } \\
\text { System }\end{array}$ & $\begin{array}{l}\text { Com- } \\
\text { pound }\end{array}$ & $\begin{array}{l}\mathrm{D} \\
\left(10^{-10} \mathrm{~m}^{2} \mathrm{~s}^{-1}\right)\end{array}$ & $\begin{array}{l}\text { Bound molar } \\
\text { fraction }(\%)^{*}\end{array}$ & $\begin{array}{l}\mathrm{Ka} \\
(\mathrm{L} / \mathrm{mol})\end{array}$ \\
\hline- & RVC & $5.21 \pm 0.04$ & - & - \\
\hline- & HP- $\beta C D$ & $2.47 \pm 0.01$ & - & - \\
\hline- & LUV & $0.80 \pm 0.02$ & - & - \\
\hline RVC in HP- $\beta C D$ & RVC & $4.47 \pm 0.01$ & 27 & 128 \\
\hline LUV $_{\text {RVC }}$ & RVC & $4.61 \pm 0.02$ & 14 & 22 \\
\hline
\end{tabular}

The data in Table 4 confirmed that RVC binds more strongly to $\mathrm{HP}-\beta C D\left(\mathrm{Ka}=128 \mathrm{M}^{-1}\right)$ than to egg PC liposomes $(\mathrm{Ka}=$ $\left.22 \mathrm{M}^{-1}\right)$, thus explaining the better performance of $\mathrm{HP}-\beta \mathrm{CD}$ in sustaining the release of RVC in the dialysis experiment (Fig. 5). Similar results were previously found for another anesthetic, prilocaine that was found to preferentially bind to $\beta C D$ than to egg PC liposomes ${ }^{[21]}$.

It is believed that the sustained release profile observed in Fig. 5 results from the anesthetic complexation with the cyclodextrin, also evidenced by the increase in aqueous solubility of the anesthetic $\mathrm{RVC}^{[19]}$, that retards the kinetics of RVC transfer through the dialysis membrane. The same applies for the $\mathrm{LUV}_{\mathrm{RVC}}$ system, were the anesthetics embedded in the lipid bilayer dissociate slowly in the aqueous media ${ }^{[4]}$. However, the association constant between RVC and liposomes is weaker than that between RVC and HP- $\beta C D$, justifying the shorter release time of $\mathrm{LUV}_{\mathrm{RVC}}$ than RVC: HP- $\beta \mathrm{CD}$.

\section{Conclusion}

The analytical methodology for quantifying ropivacaine was considered fast and feasible, displaying linearity in the concentration range of $0.08-1.16 \mathrm{mM}$ RVC, with accuracy and precision, satisfying the analytical requirements for validation of both ICH and ANVISA. Furthermore, the limit of quantification makes the method suitable for use in release assays, for the quantification of RVC in the aqueous phase of different drug-delivery systems.

Release kinetics experiments, employing the validated HPLC methodology for RVC quantification, allowed the comparison of 2 different DDS. The results indicated a slower release rate when RVC formed inclusion complexes with HP$\beta C D$ than when it was encapsulated into liposomes. In both cases drug the release was prolonged, which is highly desirable to prolong the anesthesia time, in vivo. NMR experiments revealed the stronger binding of RVC to cyclodextrins than to liposomes, justifying the extended release profile of the RVC: HP- $\beta C D$ formulation.

Acknowledgments: The authors declare they have no conflict of interest regarding the data reported in this manuscript. They also thank São Paulo Research Foundation (FAPESP \# 06/00121-9) for the financial support and Cristália Prod. Quím Farmac Ltd, for kindly supplying ropivacaine salt.

\section{References}

1. Strichartz, G. Local anesthetics. (1987) Springer, Berlin Heidelberg New York London Tokyo.

PubMed $\mid$ CrossRef $\mid$ Others

2. McLure, H. A., Rubin, A. P. Review of local anaesthetic agents. (2005) Minerva Anestesiol 71(3): 59-74. PubMed | CrossRef $\mid$ Others

3. Lagan, G., McLure, H. A. Review of local anaesthetic agents. (2004) Curr Anaesth Crit Care. 15:247-254. PubMed | CrossRef $\mid$ Others

4. de Araujo, D. Cereda, C., Brunetto, G., et al. Pharmacological and local toxicity studies of a liposomal formulation for the novel local anaesthetic ropivacaine. (2008) J Pharm Pharmacol 60(11): 1449-1457.

PubMed | CrossRef | Others

5. Zuo, M., Duan, G., Ge, Z. Simultaneous determination of ropivacaine and antipyrine by high performance liquid chromatography and its application to the in vitro transplacental study. (2004) Biomed Chromatogr 18(9): 752-755. PubMed | CrossRef | Others

6. Cánovas Martínez, L., Barros Núñez, C., Gallardo, E., et al. Clinical effects and pharmacokinetics of ropivacaine and bupivacaine for epidural analgesia during labor. (2004) Rev Esp Anestesiol Reanim 51(3): 128-132.

PubMed | CrossRef | Others

7. Dollo, G., Thompson, D., Le Corre, P., et al. Inclusion complexation of amide-typed local anesthetics with beta-cyclodextrin and its derivatives. III. Biopharmaceutics of bupivacaine-SBE7-beta CD complex following percutaneous sciatic nerve administration in rabbits.(1998) Int J Pharm 164(1-2): 11-19.

PubMed | CrossRef | Others

8. Grant, G.J., Bansinath, M. Liposomal delivery systems for local anesthetics. (2001) Reg Anesth Pain Med 26(1): 6163.

PubMed | CrossRef $\mid$ Others

9. de Paula, E. Cereda, C.M., Fraceto, L.F., et al. Micro and nanosystems for delivering local anesthetics. (2012) Expert Opin Drug Deliv 9(12): 1505-1524. PubMed |CrossRef | Others

10. Rogobete, A.F., Dragomirescu, M., Bedreag, O.H., et al. New aspects of controlled release systems for local anaesthetics: A review. (2016)Trend Anaesth Crit Care 9: 27-34. PubMed | CrossRef | Others

11. Koehler, A., Oertel, R., Kirch, W. Simultaneous determination of bupivacaine, mepivacain, prilocaine and ropivacain in human serum by liquid chromatography-tandem mass 
Citation: Vieira, A.L.N., et al. Validation of an HPLC Method Devised for the Quantitative Determination of Ropivacaine in Drug-Delivery Systems. (2018) J Anal Bioanal Sep Tech 3(1): 14- 20.

spectrometry. (2005) J Chromatogr A 1088(1-2): 126-130. PubMed |CrossRef | Others

12. Sawaki, K., Okubo, M., Shimomiya, T. Evaluation of high-performance liquid chromatography and mass spectrometry method for pharmacokinetic study of local anesthetic ropivacaine in plasma. (2009) Biomed Res 30(6): 319-324.

PubMed |CrossRef | Others

13. Qin, W.W., Jiao, Z., Zhong, M.K., et al. Simultaneous determination of procaine, lidocaine, ropivacaine, tetracaine and bupivacaine in human plasma by high-performance liquid chromatography. (2010) J Chromatogr B Analyt Technol Biomed Life Sci 878(15-16): 1185-1189.

PubMed | CrossRef | Others

14. Jönsson, J., Andersson, M., Melander, C., et al. Automated liquid membrane extraction for high-performance liquid chromatography of Ropivacaine metabolites in urine. (2000) J Chromatogr A 870(1-2): 151-157. PubMed | CrossRef | Others

15. Zhou, Z., Ye, J., Chen, L., Ma, A., Zou, F. Simultaneous determination of ropivacaine, bupivacaine and dexamethasone in biodegradable PLGA microspheres by high performance liquid chromatography. (2010) Yakugaku Zasshi 130(8): 1061-1068.

PubMed | CrossRef | Others

16. ICH. International Conference on Harmonisation of Technical Requirements for Registration of Pharmaceuticals for Human Use. (1996) Q2B. Validation of Analytical Procedures: Text and Methodology. PubMed |CrossRef $\mid$ Others

17. ANVISA. "Guia de Validação de Métodos Analíticos e Bioanalíticos.” RE 899 de29 de maio de 2003 (2003). PubMed $\mid$ CrossRef $\mid$ Others

18. United States Pharmacopeia, USP 41, NF36, page 3677 (2018). Available at: Docld: GUID-66AB9059-EFBC48BA-BEA9-42147E2AFD32_1_en-US.

PubMed |CrossRef $\mid$ Others

19. de Araujo, D., Tsuneda, S., Cereda, C., et al. Development and pharmacological evaluation of ropivacaine-2-hydroxypropyl-beta-cyclodextrin inclusion complex. (2008) Eur J Pharm Sci 33(1): 60-71. PubMed |CrossRef |Others

20. Paavola, A., Yliruusi, J., Kajimoto, Y., et al. Controlled release of lidocaine from injectable gels and efficacy in rat sciatic nerve block. (1995) Pharm Res 12(12): 1997-2002. PubMed | CrossRef | Others

21. Cabeça, L.F., Figueiredo, I.M., de Paula, E., et al. Prilocaine-cyclodextrin-liposome: effect of $\mathrm{pH}$ variations on the encapsulation and topology of a ternary complex using ${ }^{1} \mathrm{H}$ NMR. (2011) Magn Reson Chem 49(6): 295-300. PubMed |CrossRef |Others

22. Cereda, C.M., Tofoli, G.R., Maturana, L.G., et al. Local neurotoxicity and myotoxicity evaluation of cyclodextrin complexes of bupivacaine and ropivacaine. (2012) Anesth Analg 115(5): 1234-1241. PubMed | CrossRef | Others

23. da Silva, C.M.G., Franz-Montan, M., Limia, C.E.G., et al. Encapsulation of ropivacaine in a combined (donor-acceptor, ionic-gradient) liposomal system promotes extended anesthesia time. (2017) PLoS One 12(10): e0185828. PubMed | CrossRef |Others

24. Prado, A.R., Yokaichiya, F., Franco, M.K.K.D., et al. Complexation of oxethazaine with 2-hydroxypropyl- $\beta$-cyclodextrin: increased drug solubility, decreased cytotoxicity and analgesia at inflamed tissues. (2017) J Pharm Pharmacol 69(6): 652-662.

PubMed | CrossRef | Others

Submit your manuscript to Ommega Publishers and we will help you at every step:

- We accept pre-submission inquiries

- Our selector tool helps you to find the most relevant journal

- We provide round the clock customer support

- Convenient online submission

- Thorough peer review

- Inclusion in all major indexing services

- Maximum visibility for your research

Submit your manuscript at

OMmEga Publishers https://www.ommegaonline.org/submit-manuscript 